\title{
Response of Groundnut (Arachis hypogaea L.) Genotypes to Irrigation with Magnetized Saline Water
}

\author{
Elsayed A. A. Abdelraouf ${ }^{1}$ and Shimaa M. Abdelaziz ${ }^{2}$
}

\begin{abstract}
A study was conducted at Etay Elbaroud Research Station, Agriculture Research Center, MALR, Egypt, to investigate the effect of magnetic saline irrigation water on growth of two groundnut genotypes. The experiment was carried out in randomized complete block design in a splitsplit-plot arrangement with three replicates. The main plot represented by four salt concentrations $(0,25,50$ and 100 $\mathrm{mM} \mathrm{NaCl}$ ), the sub-plot was two groundnut genotypes (Giza 6 and N.C.) and the sub-subplot was two treatments (with or without magnetized irrigation solution). Seeds were sown in pots containing $0.5 \mathrm{Kg}$ pre-washed quartz sand and irrigated three times per week by adding $100 \mathrm{~mL}$ of irrigation solution consisting of base nutrient solution and the salt level exposed to with or without a magnetic field, to each pot. After three weeks from sowing the whole plants were collected. The results indicated that increasing salt stress decreased the all growth parameters and shoot/root ratio on fresh and dry weight basis of the two groundnut genotype. However, moisture content of whole plant, shoots and roots were increased with increasing salt stress. Electrolytes leakage generally decreased with increasing salt stress. Chlorophyll $a, b$ and total chlorophyll content increased at high level of salt stress (100 $\mathrm{mM} \mathrm{NaCl})$. The N.C. genotype was more sensitive to salinity than the Giza 6 genotype for most growth attributes. The magnetized saline irrigation water had no significant effect on alleviation of salt stress to the two groundnut genotypes.
\end{abstract}

Keywords: Salt stress, groundnut, magnetic water, electrolytes leakage, chlorophyll content.

\section{INTRODUCTION}

Salinity in soil or water is one of the major abiotic stress especially in arid and semi- arid regions and can severely limit crop production (Shannon, 1998). It is an ever-increasing problem throughout the world and imposes major constraints to food production (Hasegawa et al., 2000; Tester and Davenport, 2003). Globally, nearly 100 million hectares of land is affected by salinity which accounts for $6-7 \%$ of the total arable land (Munns and James, 2003). Two million feddans in Egypt suffer from salinization problems (FAO, 2007). It has negative affect on plants through three components: osmotic, nutrition's and toxic stresses (Läuchli and Epstein, 1990; Munns, 1993). When plants are exposed

\footnotetext{
DOI: 10.21608/ASEJAIQJSAE.2020.120559

${ }^{1}$ Nat. Resources\& Agri. Eng. Dep. Fac. Agric. Damanhur Unv., Egypt.

${ }^{2}$ Soil, Water and Enviro. Inst., Agric. Res. Cent., Giza, Egypt.

Received August 27, 2020, Accepted, September 30, 2020.
}

to salinity, growth and fruits tend to decline, with consequent reduction in the economic outcome. The use of saline water in cultivation, especially scarcity regions requires innovative and sustainable research, and an appropriate transfer of technologies. There is a vital need to use the magnetic field during irrigation with saline water.

Numerous studies have been carried out to investigate the effects of magnetic fields on the biological systems. Magnetized water is obtained by passing the water through the permanent magnets or through the electro-magnetic installed in/on a feed pipeline. As documented in the literature, there are some beneficial effects of magnetic field treatments either the pre-sowing seed treatment or irrigation with magnetized water. Magnetic field improves plant growth characteristics (Mostafazadeh-Fard et al., 2011; Radhakrishnan and Kumari, 2012), influence on the chemical composition of plants (Radhakrishnan and Kumari, 2012). A magnetic treatment of saline and recycled water prior to irrigation of celery, peas and snow peas slightly increases the biomass production and yield per unit water application, for celery and snow peas, as compared to irrigation with untreated water (Maheshwari and Grewal, 2009). However, it was not clear if these findings were connected to the salinity. Therefore, more studies on this issue are required for further verification and interpretation of this phenomenon.

Groundnut (Arachis hypogaea L.) is considered one of the most important edible oil crops in Egypt, due to its seeds have high nutritive value. In addition to the seed oil importance for industrial purposes, it contains about $50 \%$ oil, $25-30 \%$ protein, $20 \%$ carbohydrates and $5 \%$ fibers. Groundnut is classified as moderately sensitive crop to salinity (Ayers and Westcot, 1985). Hence, this research was conducted to study the extent to which the salt stress of two groundnut genotypes could be alleivated by exposing the saline irrigation water to a magnetic field. 


\section{MATERIALS AND METHODS}

A pot experiment, using sand culture technique under field conditions, was carried out during summer season 2020 at Etay Elbaroud Research Station, El Beheira Governorate, Ministry of Agriculture and Land Reclamation (MALR), Agriculture Research Center, Giza, Egypt to investigate the response of two groundnut (Arachis hypogaea L.) genotypes (Giza 6 and N.C.) obtained from Agriculture Research Center, Ministry of Agriculture and Land Reclamation (MALR), Egypt.

To irrigation with saline water exposed to or without a magnetic field. A randomized complete block design in a split-split-plot array with three replicates was used. The main plot was four salt concentrations $(0,25,50$ and $100 \mathrm{mM} \mathrm{NaCl}$ ), the sub-plot was two groundnut genotypes (Giza 6 and N.C.) and the sub-subplot was two treatment (with or without magnetized irrigation solution).

Five seeds of every groundnut genotype were sown in plastic pot $(12 \mathrm{~cm}$ inside diameter and $9 \mathrm{~cm}$ depth with holes in the bottom for drainage) containing $0.5 \mathrm{~kg}$ pre-washed quartz sand of size fraction between 0.25 and $1 \mathrm{~mm}$ (Hewitt, 1966). Each pot was irrigated three times per week with $100 \mathrm{~mL}$ of nutrient solution treated with or without magnetic, which contains both one-tenth strength modified Hoagland and Arnon nutrient solution (Hewitt, 1966), and the tested salt concentrations (0, 25, 50 or $100 \mathrm{mM} \mathrm{NaCl}$ ). The magnetized irrigation solution has been exposed to magnetic field by passing through a magnetic device supplied by Nefertari Biomagnetic Company before the application to the pot. The concentrations of macronutrients in the base solution were $16.87,8.47,11.92,29.99,12.00,4.78$, and $6.38 \mathrm{mg} \mathrm{L}^{-1}$ for $\mathrm{N}^{-\mathrm{NO}_{3}}, \mathrm{~N}-\mathrm{NH}_{4}, \mathrm{P}, \mathrm{K}, \mathrm{Ca}, \mathrm{Mg}$, and $\mathrm{S}$, respectively. The concentrations of micronutrients in the base solution were $0.50,0.11,0.05,0.01,0.01$ and 0.005 $\mathrm{mg} \mathrm{L}^{-1}$ for $\mathrm{Fe}, \mathrm{Mn}, \mathrm{B}, \mathrm{Zn}, \mathrm{Cu}$ and $\mathrm{Mo}$, respectively. After 10 days from sowing, the plants were thinned to three plants per pot.

After three weeks from sowing, the whole plants were collected, washed by distilled water, and then separated into shoots and roots. The fresh weight of shoots and roots, shoot height, and root length were measured. Half gram of a fresh leaf tissue from the fully expanded leaf extracted in $10 \mathrm{~mL}$ of $80 \%$ acetone during seven days in the dark to determine the chlorophyll content using the methods of Arnon (1949) and Coombs et al. (1987). The absorbance of the extract was measured using a spectrophotometer (Model Spectronic 21D) at 645 and $663 \mathrm{~nm}$ to determine the content of chlorophyll $\mathrm{a}$ and $\mathrm{b}$, respectively. Total chlorophyll was calculated by adding chlorophyll a and b. Chlorophyll a and $\mathrm{b}$ content in milligrams of chlorophyll per gram of leaf tissue was calculated according to Arnon (1949) using the following formulae:

$\mathrm{mg}$ chl.a $/ \mathrm{g}$ fresh leaf tissue $=12.7(\mathrm{D} 663)-2.69(\mathrm{D} 645) \mathrm{x}$ $\mathrm{V} /(1000 \times \mathrm{W})$

$\mathrm{mg}$ chl.b $/ \mathrm{g}$ fresh leaf tissue $=22.9(\mathrm{D} 645)-4.68(\mathrm{D} 643) \mathrm{x}$ $\mathrm{V} /(1000 \times \mathrm{W})$

Where $\mathrm{D}=$ Absorbance at wavelength 645 or $663 \mathrm{~nm}$

$\mathrm{V}=$ Volume $(\mathrm{ml})$ of the ethanol extract

$\mathrm{W}=$ Fresh weight of leaf tissue

Electrolyte leakage was used to assess membrane permeability according to Dkhil and Denden (2012). The fresh leaf uniform size discs were cut $\left(1 \mathrm{~cm}^{2}\right)$ and put in closed test tubes containing $10 \mathrm{ml}$ of distilled water and incubated at room temperature for $24 \mathrm{~h}$ and subsequently electrical conductivity of the solution $\left(E_{1}\right)$ was recorded. The samples were then autoclaved at $120^{\circ} \mathrm{C}$ for $20 \mathrm{~min}$ and the final electrical conductivity $\left(E_{2}\right)$ was obtained after cooling the solution to room temperature. The Electrolyte leakage was calculated as $\mathrm{EC}_{1} / \mathrm{EC}_{2}$ and expressed as percentage.

The plant samples were then dried at $70^{\circ} \mathrm{C}$ for 48 hours till constant weight and the dry weight of shoots and roots were measured. The moisture content as a percentage of the whole plant, shoots, and roots were obtained by (fresh weight - dry weight)/ fresh weight $* 100$. The shoot/root ratio on fresh and dry weight basis of the whole plant, shoots, and roots were calculated. The relative decrease expressed as: (control - treatment) / control * 100 of most parameters was calculated.

The analysis of variance was calculated using the CoStat 6.311 Statistical Analysis Software (CoStat, 2005) and the differences are identified among means by Fisher's Least Significant Difference (LSD) test at 0.05 probability level.

\section{RESULTS AND DISCUSSION}

\section{Plant weight}

Whole Plant: The whole plant weight is an important parameter determining the plant growth. The whole plant fresh weight of the two groundnut genotypes decreased significantly with increasing salt concentrations (Table 1). There were significant differences among groundnut genotypes with respect to the whole plant fresh weight under salt stress. Also, there were significant differences between the interaction of salinity and groundnut genotypes on the whole plant fresh weight (Fig. 1). The relative decreases in whole plant fresh weight of Giza 6 with increasing salinity were $-1.1,28.8$, and $69.8 \%$ for 25,50 , and 100 $\mathrm{mM} \mathrm{NaCl}$ levels, respectively as compared to the control $(0 \mathrm{mM} \mathrm{NaCl})$ with mean relative decrease 32.5 $\%$, while, the relative decreases of N.C were $20.5,25.9$, 
and $77.8 \%$ for 25,50 , and $100 \mathrm{mM} \mathrm{NaCl}$ levels, respectively with mean relative decrease $41.4 \%$. On the other hand, there were no significant differences between magnetic treatments and between salinity $\mathrm{X}$ magnetic, genotypes $\mathrm{X}$ magnetic and salinity $\mathrm{X}$ genotypes $\mathrm{X}$ magnetic interactions on the whole plant fresh weight.

Table 1. Main effects of salinity concentrations, genotypes and magnetic on fresh and dry weights of whole plants, shoots and roots and shoot/root ratio of groundnut

\begin{tabular}{|c|c|c|c|c|c|c|c|c|}
\hline \multirow[t]{2}{*}{ Treatment } & \multicolumn{3}{|c|}{$\begin{array}{l}\text { Fresh weight } \\
\left(\text { g plant }^{-1}\right)\end{array}$} & \multicolumn{3}{|c|}{$\begin{array}{l}\text { Dry weight } \\
\left.\text { (g plant }^{-1}\right)\end{array}$} & \multicolumn{2}{|c|}{$\begin{array}{c}\text { Shoot/Root } \\
\text { Ratio }\end{array}$} \\
\hline & Whole & Shoot & Root & Whole & Shoot & Root & $\begin{array}{c}\text { Fresh } \\
\text { Weight }\end{array}$ & $\begin{array}{c}\text { Dry } \\
\text { Weight }\end{array}$ \\
\hline \multicolumn{9}{|c|}{ Salinity conc. $(\mathrm{mM} \mathrm{NaCl})$} \\
\hline 0 & $4.66^{\mathrm{a}}$ & $3.38^{\mathrm{a}}$ & $1.28^{\mathrm{a}}$ & $0.71^{\mathrm{a}}$ & $0.45^{\mathrm{a}}$ & $0.26^{\mathrm{a}}$ & $2.69^{\mathrm{a}}$ & $1.80^{\mathrm{b}}$ \\
\hline 25 & $4.26^{\mathrm{a}}$ & $2.76^{\mathrm{b}}$ & $1.51^{\mathrm{a}}$ & $0.52^{\mathrm{b}}$ & $0.37^{\mathrm{b}}$ & $0.15^{\mathrm{b}}$ & $1.92^{\mathrm{b}}$ & $2.48^{\mathrm{a}}$ \\
\hline 50 & $3.38^{\mathrm{b}}$ & $2.08^{\mathrm{c}}$ & $1.29^{\mathrm{a}}$ & $0.39^{\mathrm{c}}$ & $0.26^{\mathrm{c}}$ & $0.13^{\mathrm{b}}$ & $1.63^{\mathrm{c}}$ & $2.04^{\mathrm{b}}$ \\
\hline 100 & $1.24^{\mathrm{c}}$ & $0.81^{\mathrm{d}}$ & $0.44^{\mathrm{b}}$ & $0.12^{\mathrm{d}}$ & $0.08^{\mathrm{d}}$ & $0.04^{\mathrm{c}}$ & $2.06^{\mathrm{b}}$ & $1.99^{\mathrm{b}}$ \\
\hline $\mathrm{LSD}_{0.05}$ & 0.69 & 0.43 & 0.30 & 0.08 & 0.05 & 0.04 & 0.27 & 0.44 \\
\hline \multicolumn{9}{|l|}{ Genotypes } \\
\hline Giza 6 & $3.92^{\mathrm{a}}$ & $2.58^{\mathrm{a}}$ & $1.34^{\mathrm{a}}$ & $0.49^{\mathrm{a}}$ & $0.33^{\mathrm{a}}$ & $0.17^{\mathrm{a}}$ & $1.99^{\mathrm{b}}$ & 2.07 \\
\hline $\mathrm{NC}$ & $2.85^{\mathrm{b}}$ & $1.93^{\mathrm{b}}$ & $0.92^{\mathrm{b}}$ & $0.38^{\mathrm{b}}$ & $0.25^{\mathrm{b}}$ & $0.13^{\mathrm{b}}$ & $2.16^{\mathrm{a}}$ & 2.08 \\
\hline $\mathrm{LSD}_{0.05}$ & 0.30 & 0.17 & 0.14 & 0.03 & 0.02 & 0.01 & 0.15 & $\mathrm{~ns}$ \\
\hline $\begin{array}{l}\text { Magnetic } \\
\text { without }\end{array}$ & 3.33 & 2.25 & 1.09 & 0.42 & 0.28 & 0.14 & 2.12 & 1.95 \\
\hline with & 3.44 & 2.26 & 1.17 & 0.45 & 0.30 & 0.15 & 2.02 & 2.21 \\
\hline $\mathrm{LSD}_{0.05}$ & $\mathrm{~ns}$ & $\mathrm{~ns}$ & $\mathrm{~ns}$ & ns & $\mathrm{ns}$ & $\mathrm{ns}$ & ns & $\mathrm{ns}$ \\
\hline
\end{tabular}

ns: Not significant.

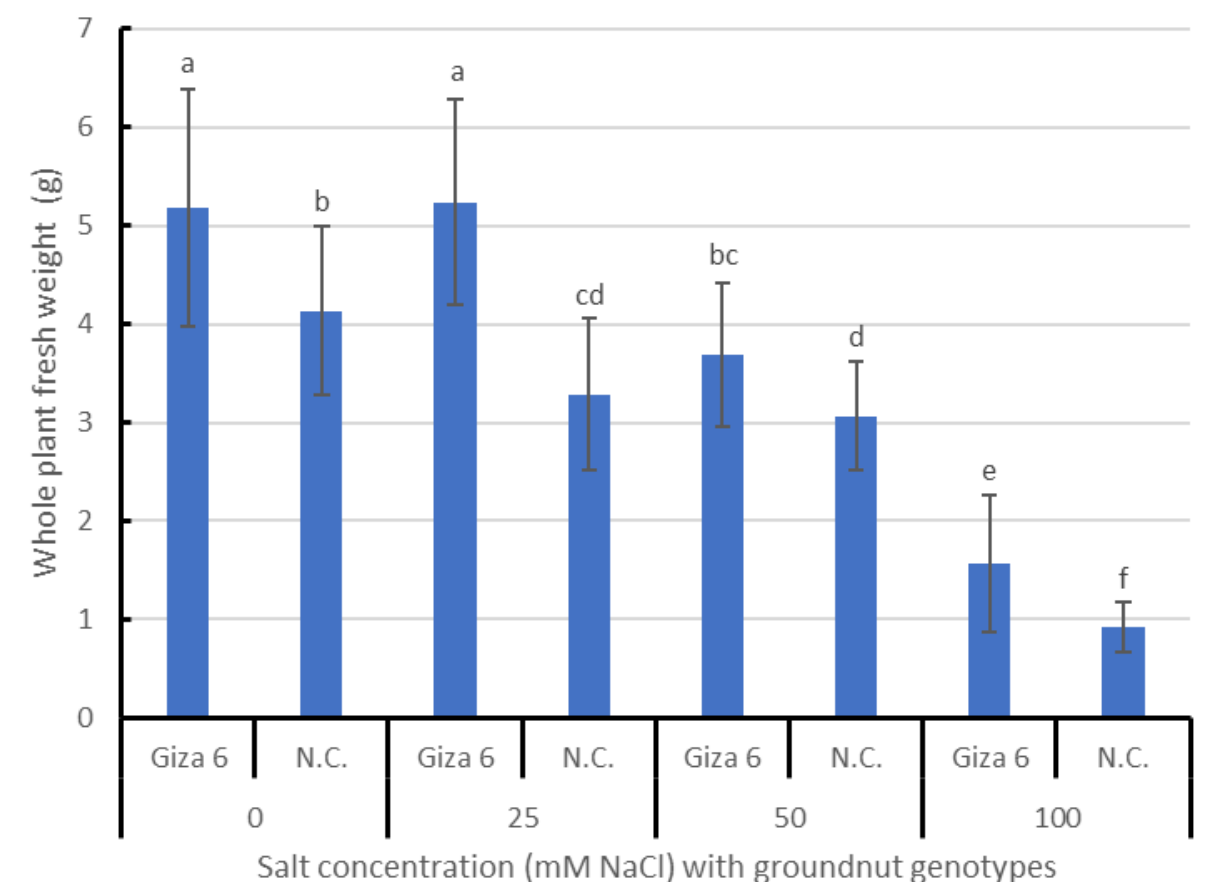

Fig. 1. Means of whole plant fresh weight of the two groundnut genotypes as affected by salinity concentrations 
Whole plant dry weight of the two groundnut genotypes significantly decreased under Salt stress (Table 1). There were significant differences among groundnut genotypes with respect to the whole plant dry weight under salt stress. While there were no significant differences between the interaction of salinity and groundnut genotypes on the whole plant dry weight. The relative decreases in whole plant dry weight of Giza 6 with increasing salinity were $23.1,45.7$, and $79.2 \%$ for 25,50 , and $100 \mathrm{mM} \mathrm{NaCl}$ levels, respectively with mean relative decrease $49.3 \%$, while, the relative decreases of N.C were 31.9, 43.6, and $86.9 \%$ for 25 , 50 , and $100 \mathrm{mM} \mathrm{NaCl}$ levels, respectively with mean relative decrease $54.1 \%$. This mean that the N.C genotype was more sensitive to salt stress than Giza 6 . There were no significant differences between magnetic treatments and between salinity X magnetic, genotypes $X$ magnetic and salinity $X$ genotypes $X$ magnetic interaction on the whole plant dry weight.

Shoot: Shoot fresh weight of the two groundnut genotypes decreased significantly with increasing $\mathrm{NaCl}$ concentration (Table 1). There were significant differences between groundnut genotypes with respect to shoot fresh weight under salt stress. Also, there were significant differences with respect to shoot fresh weight between the interaction of salt stress and groundnut genotypes (Fig. 2). The relative decreases in shoot fresh weight of Giza 6 with increasing salinity were $12.6,39.7$, and $74.1 \%$ for 25,50 , and $100 \mathrm{mM}$ $\mathrm{NaCl}$ levels, respectively with mean relative decrease
$42.1 \%$, while, the relative decreases of N.C were 25.7, 36.6 , and $78.7 \%$ for 25,50 , and $100 \mathrm{mM} \mathrm{NaCl}$ levels, respectively with mean relative decrease $47.0 \%$. On the other hand, there were no significant differences between magnetic treatments and between salinity $\mathrm{X}$ magnetic, genotypes $\mathrm{X}$ magnetic and salinity $\mathrm{X}$ genotypes $\mathrm{X}$ magnetic interactions on the shoot fresh weight.

Shoot dry weight of groundnut genotypes significantly decreased due to salt stress (Table 1). Also, there were significant differences between the two studied groundnut genotypes with respect to shoot dry weight under salt stress. However, no significant effect of magnetic treatment and of all the interaction levels between the treatments on shoot dry weight.

Roots: Root fresh weight of groundnut genotypes significantly decreased with increasing salt stress (Table 1). There were significant differences between groundnut genotypes with respect to root fresh weight under salt stress. Also, there were significant differences with respect to root fresh weight between the interaction of salt stress and groundnut genotypes (Fig. 3). The relative decreases in root fresh weight of Giza 6 with increasing salinity were $-37.9,-0.2$, and $58.4 \%$ for 25 , 50 , and $100 \mathrm{mM} \mathrm{NaCl}$ levels, respectively with mean relative decrease $6.7 \%$, while, the relative decreases of N.C were $7.4,-1.5$, and $75.3 \%$ for 25,50 , and $100 \mathrm{mM}$ $\mathrm{NaCl}$ levels, respectively with mean relative decrease $27.0 \%$.

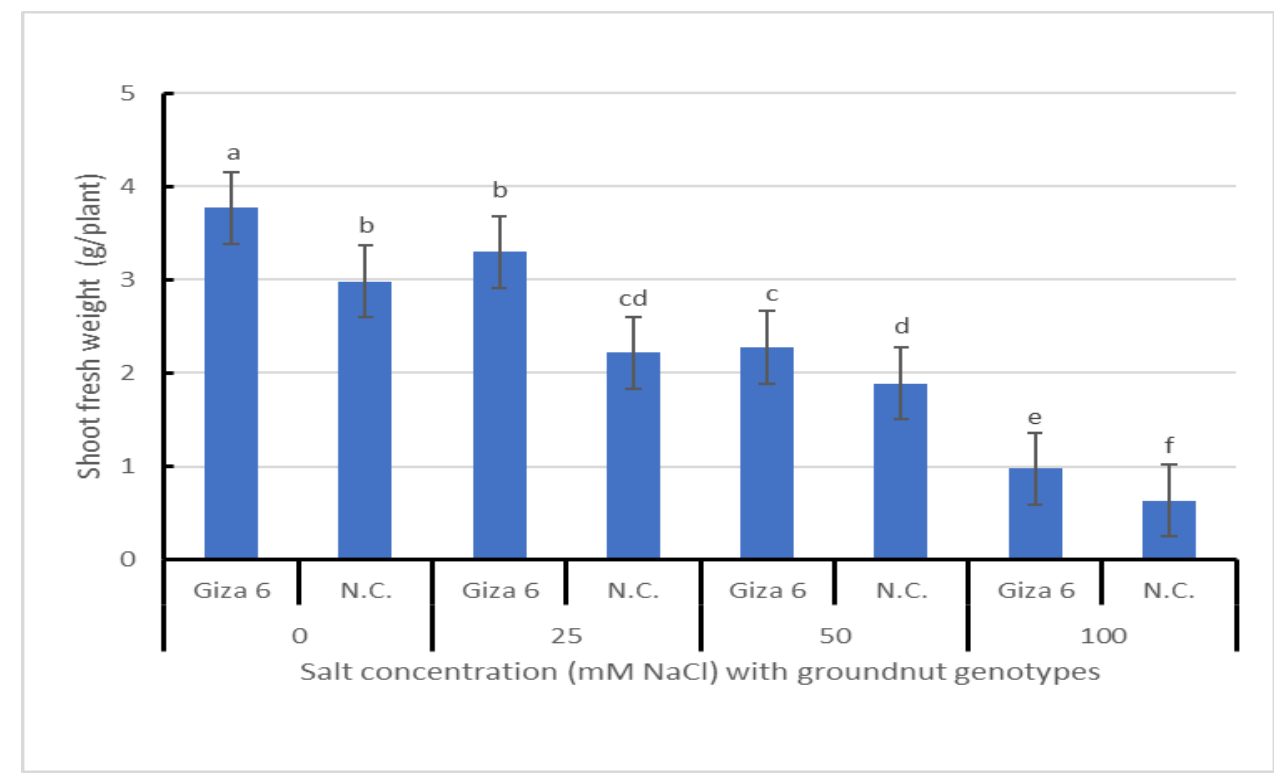

Fig. 2. Means of shoot fresh weight of the two groundnut genotypes as affected by salinity concentrations 


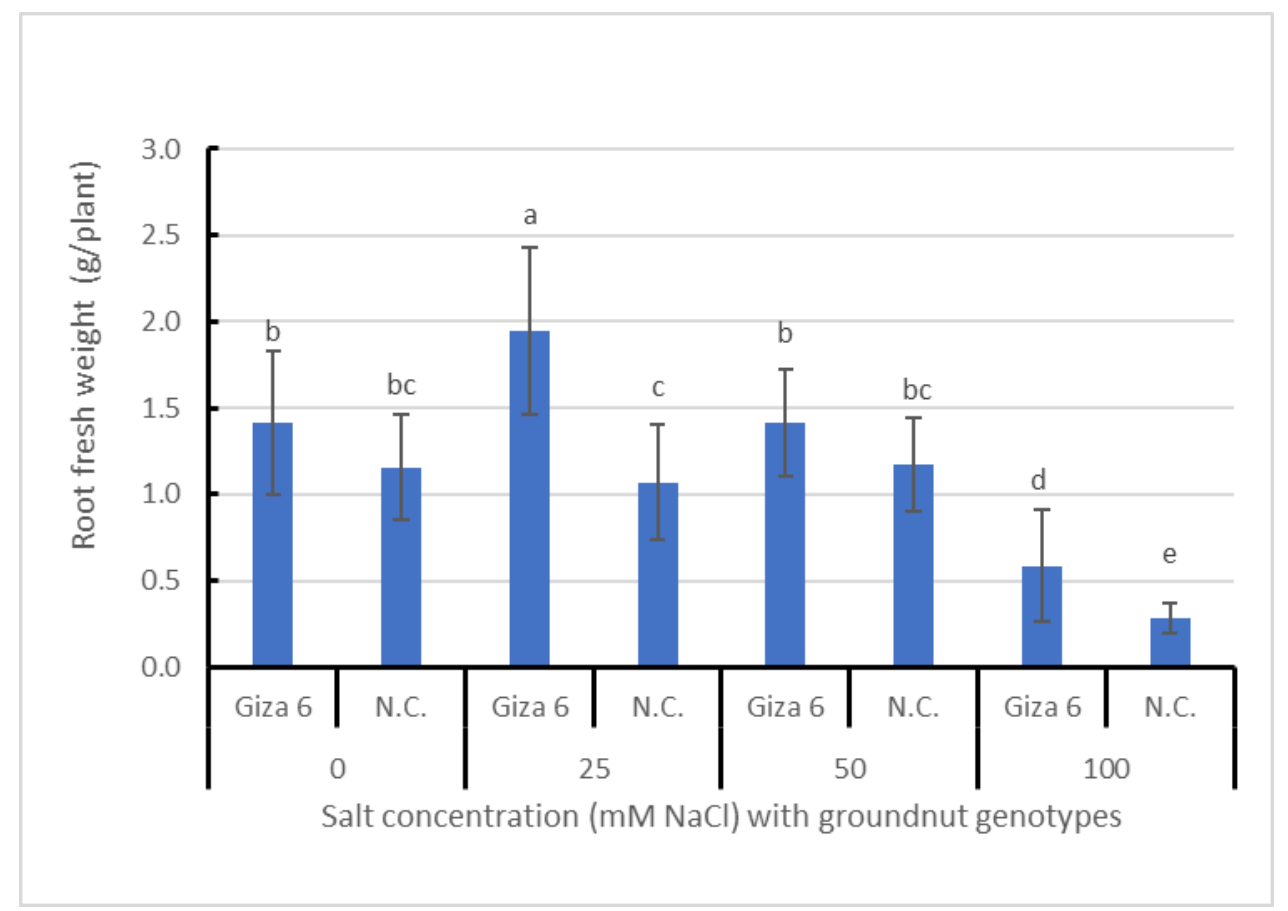

Fig. 3. Means of root fresh weight of the two groundnut genotypes as affected by salinity concentrations

Root dry weight of groundnut genotypes significantly decreased due to salt stress (Table 1). Moreover, there were significant differences between groundnut genotypes with respect to root dry weight under salt stress. On the other hand, no significant differences were observed between magnetic treatments and between all the interaction levels of these treatments, on root dry weight.

These results are in according with the already published results which reported that increasing salt concentration negatively affects the root and shoot development (Farhoudi et al., 2015; Saad-Allah, 2015). The reduction of plant growth under salt stress may either be due to excessive ions, $\mathrm{Na}^{+}$and $\mathrm{Cl}^{-}$ accumulation in the plant tissues (Yousef and AlSaadawi, 1997). High foliar concentration of $\mathrm{Na}^{+}$ion can reduce $\mathrm{CO}_{2}$ assimilation because of ionic toxicity (Cachorro et al., 1993). Also, due to generation of osmotic stress leading to reduce in water absorbance by plant and cell division and differentiation (Nikee et al., 2014). It has been reported that saline condition significantly reduced net photosynthetic rates, increased energy losses for salt exclusion mechanism, largely decreased uptake of nutrient and finally reduced plant growth (Seemann and Sharkey, 1986). While the effect of magnetic on the growth under salt stress the results were disagree with those reported by Gao et al. (2017) on cotton seedlings.

Shoot/Root ratio: The shoot/root ratio, on fresh weight basis, significantly decreased under salt stress, while, the shoot/root ratio, on dry weight basis, significantly increased at $25 \mathrm{mM} \mathrm{NaCl}$ only (Table 1). Also, there were significant differences between groundnut genotypes and salt salinity levels $\mathrm{X}$ magnetic interaction in shoot/root ratio on fresh weight basis. Where the highest value was 2.74 to Giza 6 at $0 \mathrm{mM} \mathrm{NaCl}$ and the lowest value was 1.62 to Giza 6 at $50 \mathrm{mM} \mathrm{NaCl}$. While there were no significant differences of the other factors and different interactions on shoot/root ratio on fresh and dry weight basis. It could be concluded that the magnitude of reduction of root growth was greater than that of shoot under salinity stress. This indicates that roots of the studied groundnut genotypes are more sensitive to salinity stress than shoots. It is also, clear that the higher values of shoot/root ratio on dry weight basis than on fresh weight basis could be due to lower moisture content in shoots than in roots. These results agree with that obtained by Abdelraouf and Elgarhy (2017) who observed that the roots growth of soybean genotypes and broad bean cultivars were more adversely affected by salinity than the shoots.

\section{Shoot length}

Shoot length of groundnut genotypes significantly decreased with increasing salt stress (Table 2). Also, there were significant effect for salinity levels $\mathrm{X}$ magnetic interaction on shoot length. On the other hand, there were no significant effects of genotypes, magnetic factors and other different levels of interactions on shoot length. These results agree with those reported by 
Aydinşakir et al. (2015) and Saad-Allah (2015) and disagree with those reported by Aly et al. (2015).

\section{Root length}

The root length of groundnut genotypes significantly decreased with increasing salinity levels (Table 2). Also, there were significant differences between groundnut genotypes and between the interaction of salinity levels and magnetic on the root length. However, there were no significant effect of magnetic factor and between the other levels of interactions on the root length. These results agree with those obtained by Aydinşakir et al. (2015) and Saad-Allah (2015). The reason that the roots and shoots length are affected negatively by salt stress could be due to the fact that cytokinesis and cell expansion are inhibited and toxic effect of salts. Additionally, the increase in hormones that hinder the growth and decrease in hormones that stimulate growth can cause shorter roots and shoots lengths (Taiz and Zeiger 1998). High salinity may inhibit root and plant elongation due to slowing down the water uptake by the plant may be another reason for this decrease (Werner and Finkelstein 1995).

\section{Moisture content}

The whole plant, shoots, and roots moisture contents of groundnut genotypes significantly increased with increasing salinity levels (Table 2). The magnetic factor affected significantly the shoots and roots moisture content. There were significant effects of interaction between salinity levels and genotypes on moisture contents of whole plant (Fig. 4), shoots and roots. Moreover, the salinity levels and magnetic interaction had significant effect on whole plant and shoots moisture contents and genotypes and magnetic interaction had significant on whole plant and roots moisture contents. On the other hand, there were no significant differences between groundnut genotypes with respect to moisture content in the whole plant, shoots, and roots. There were also no significant differences between salinity levels $\mathrm{X}$ genotypes $\mathrm{X}$ magnetic interaction with respect to moisture content in the whole plant, shoots, and roots.

It is clear that the groundnut plants resisted the adverse effects of salt stress by succulence, which mean the plant increased the shoot and root fresh mass by increasing the moisture content more than the biomass production. These results are in agreement with those reported by Abdelraouf (2017), and Abdelraouf and Elgarhy (2017).

\section{Electrolytes leakage}

Salt stress generally decreased significantly membrane damage where the leakage of electrolytes from the leaf cells were decreased by increasing salt stress of the two groundnut genotypes (Table 3). NC genotype was significantly lesser membrane damaged than Giza 6. Also, magnetized water significantly decreased membrane damage of the two groundnut genotypes. On the other hand, there were no significand differences between all interaction levels of these factors on membrane damage of groundnut genotypes. The effect of salinity on moisture content results are partially agreement with those reported by Dkhil and Denden (2012) and Jeyapraba et al., (2016).

Table 2. Main effects of salinity concentrations, genotypes and magnetic on the shoot length, root length and moisture contents of groundnut genotypes.

\begin{tabular}{|c|c|c|c|c|c|}
\hline \multirow{2}{*}{ Treatment } & \multirow{2}{*}{$\begin{array}{l}\text { Shoot length } \\
(\mathrm{cm})\end{array}$} & \multirow{2}{*}{$\begin{array}{l}\text { Root length } \\
(\mathbf{c m})\end{array}$} & \multicolumn{3}{|c|}{ Moisture content $(\%)$} \\
\hline & & & Whole plant & Shoot & Root \\
\hline \multicolumn{6}{|c|}{ Salinity conc. $(\mathrm{mM} \mathrm{NaCl})$} \\
\hline 0 & $19.6^{\mathrm{a}}$ & $10.7^{\mathrm{a}}$ & $84.7^{\mathrm{d}}$ & $86.6^{\mathrm{c}}$ & $79.8^{\mathrm{b}}$ \\
\hline 25 & $16.7^{\mathrm{b}}$ & $9.5^{\mathrm{b}}$ & $87.6^{\mathrm{c}}$ & $86.6^{\mathrm{c}}$ & $89.4^{\mathrm{a}}$ \\
\hline 50 & $13.7^{\mathrm{c}}$ & $9.2^{\mathrm{b}}$ & $88.4^{\mathrm{b}}$ & $87.6^{\mathrm{b}}$ & $89.6^{\mathrm{a}}$ \\
\hline 100 & $7.6^{\mathrm{d}}$ & $5.6^{\mathrm{c}}$ & $90.4^{\mathrm{a}}$ & $90.4^{\mathrm{a}}$ & $90.1^{\mathrm{a}}$ \\
\hline $\mathrm{LSD}_{0.05}$ & 2.0 & 1.1 & 0.7 & 0.8 & 2.5 \\
\hline \multicolumn{6}{|l|}{ Genotypes } \\
\hline Giza 6 & 14.8 & $9.1^{\mathrm{a}}$ & 87.8 & 87.7 & 87.5 \\
\hline $\mathrm{NC}$ & 14.0 & $8.3^{\mathrm{b}}$ & 87.7 & 87.9 & 87.0 \\
\hline $\mathrm{LSD}_{0.05}$ & ns & 0.3 & ns & ns & ns \\
\hline $\begin{array}{l}\text { Magnetic } \\
\text { without }\end{array}$ & 14.7 & 8.8 & 87.7 & $88.0^{\mathrm{a}}$ & $86.6^{\mathrm{b}}$ \\
\hline with & 14.0 & 8.7 & 87.8 & $87.6^{\mathrm{b}}$ & $87.9^{\mathrm{a}}$ \\
\hline $\mathrm{LSD}_{0.05}$ & $\mathrm{~ns}$ & ns & ns & 0.4 & 1.0 \\
\hline
\end{tabular}




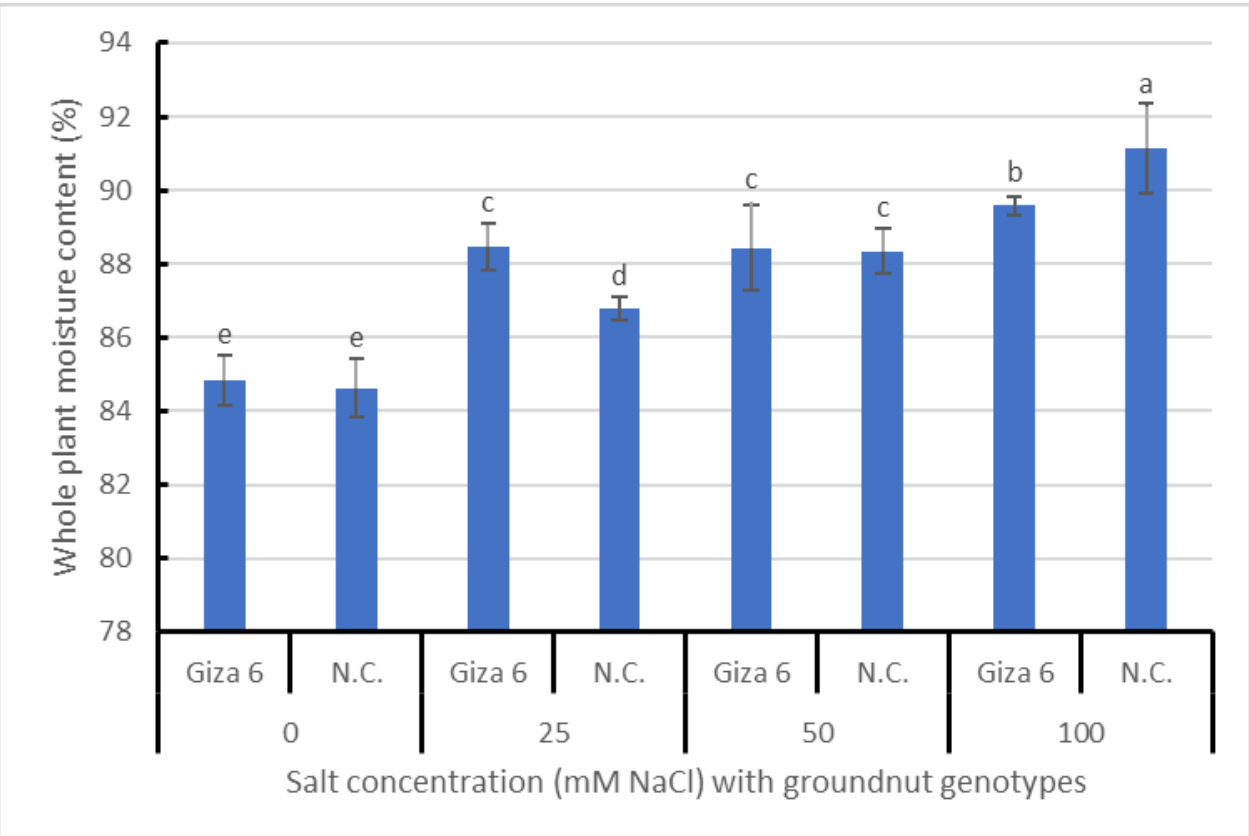

Fig. 4. The interaction between salinity concentrations and the two groundnut genotypes on whole plant moisture content

Table 3. The main effects of salinity levels, genotypes and magnetic on Electrolytes leakage and Photosynthetic pigments of groundnut genotypes

\begin{tabular}{|c|c|c|c|c|c|}
\hline \multirow{2}{*}{ Treatment } & \multirow{2}{*}{$\begin{array}{l}\text { Electrolytes } \\
\text { leakage }(\%)\end{array}$} & \multicolumn{3}{|c|}{$\begin{array}{l}\text { Photosynthetic pigments } \\
\text { (mg/g Fresh Weight) }\end{array}$} & \multirow{2}{*}{$\begin{array}{c}\text { Chl. a/Chl. b } \\
\text { ratio }\end{array}$} \\
\hline & & Chl. $a$ & Chl. $b$ & Total Chl. & \\
\hline \multicolumn{6}{|c|}{ Salinity conc. (mM NaCl) } \\
\hline 0 & $64.7^{\mathrm{a}}$ & $0.84^{\mathrm{b}}$ & $0.40^{\mathrm{b}}$ & $1.24^{\mathrm{b}}$ & 2.16 \\
\hline 25 & $71.0^{\mathrm{a}}$ & $0.80^{\mathrm{b}}$ & $0.40^{\mathrm{b}}$ & $1.20^{\mathrm{b}}$ & 2.06 \\
\hline 50 & $63.6^{\mathrm{a}}$ & $0.79^{\mathrm{b}}$ & $0.40^{\mathrm{b}}$ & $1.19^{\mathrm{b}}$ & 2.22 \\
\hline 100 & $36.9^{\mathrm{b}}$ & $1.22^{\mathrm{a}}$ & $0.68^{\mathrm{a}}$ & $1.91^{\mathrm{a}}$ & 1.86 \\
\hline $\mathrm{LSD}_{0.05}$ & 12.2 & 0.17 & 0.07 & 0.19 & ns \\
\hline \multicolumn{6}{|l|}{ Genotypes } \\
\hline Giza 6 & $64.9^{\mathrm{a}}$ & 0.86 & $0.43^{\mathrm{b}}$ & $1.29^{\mathrm{b}}$ & 2.11 \\
\hline $\mathrm{NC}$ & $53.3^{\mathrm{b}}$ & 0.97 & $0.51^{\mathrm{a}}$ & $1.47^{\mathrm{a}}$ & 2.04 \\
\hline $\mathrm{LSD}_{0.05}$ & 9.3 & ns & 0.06 & 0.12 & $\mathrm{~ns}$ \\
\hline & $1.91^{\mathrm{b}}$ \\
\hline with & $50.9^{\mathrm{b}}$ & 0.94 & 0.45 & 1.39 & $2.24^{\mathrm{a}}$ \\
\hline $\mathrm{LSD}_{0.05}$ & 11.7 & $\mathrm{~ns}$ & $\mathrm{~ns}$ & $\mathrm{~ns}$ & 0.29 \\
\hline
\end{tabular}

\section{Chlorophyll content}

Increasing salt stress generally significantly decreased chlorophyll a, b and total chlorophyll content of the two groundnut genotypes studied, except at 100 $\mathrm{mM} \mathrm{NaCl}$, but had no significant effect on chlorophyll a / chlorophyll b ratio (Table 3). There were also, significant differences between groundnut genotypes for chlorophyll $\mathrm{b}$ and total chlorophyll content and there were significant differences between the interaction of salinity levels and groundnut genotypes for total chlorophyll content (Fig. 5) and chlorophyll a, and b. Magnetic treatments had no significant effect on chlorophyll a, b and total chlorophyll content, but had significant effect on chl. a / chl. b ratio. 


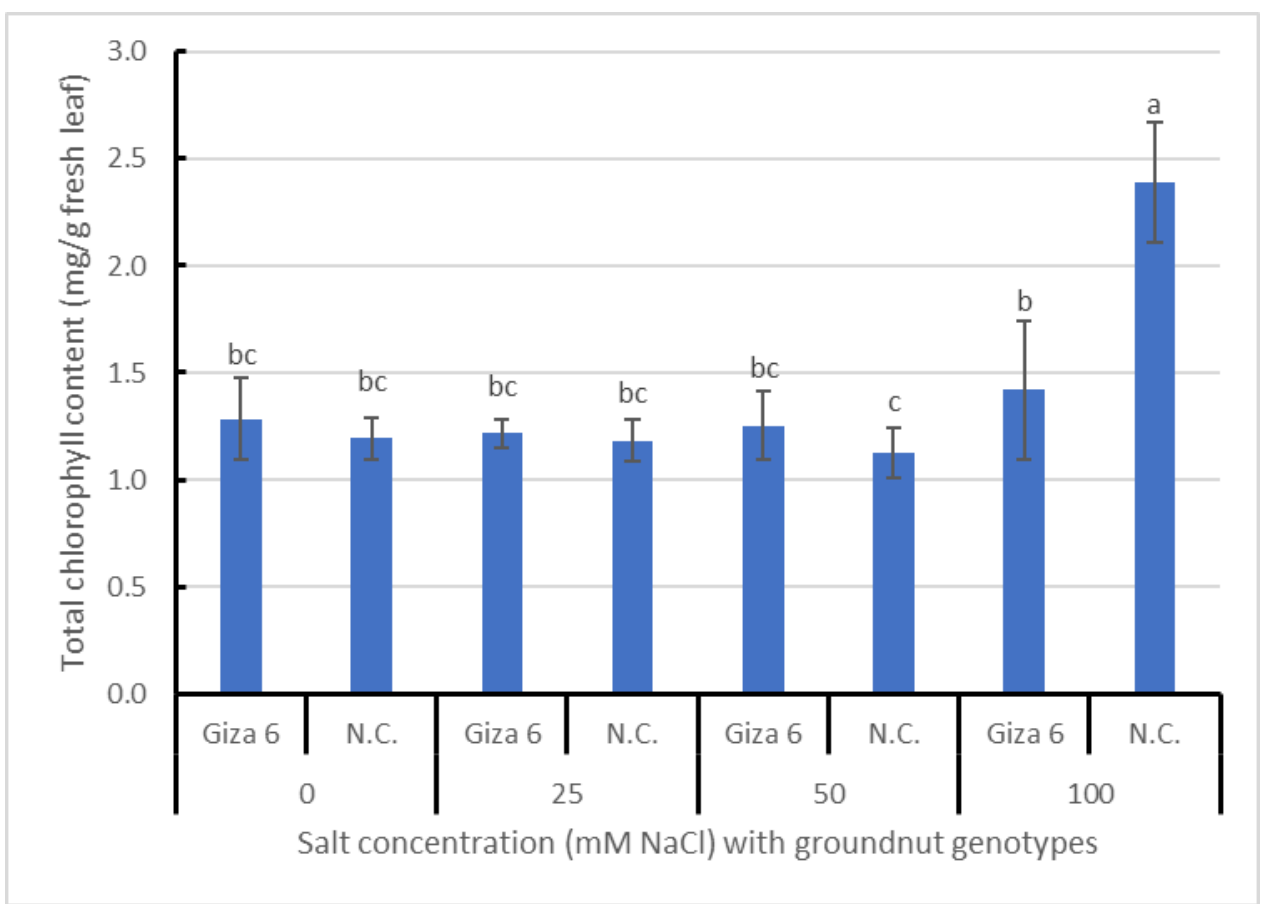

Fig. 5. The interaction between salinity concentrations and the two groundnut genotypes on total chlorophyll content

The interaction between magnetic $\mathrm{X}$ genotype had significant effect on chlorophyll $\mathrm{b}$ content and chl. a / chl. $\mathrm{b}$ ratio. The highest value of chl. $\mathrm{b}$ was 0.51 to $\mathrm{NC}$ with magnetic and the lowest value was 0.38 to Giza 6 with magnetic, while, the highest value of chl. a/chl. b was 2.49 to Giza 6 with magnetic and the lowest value was 1.73 to Giza 6 without magnetic. However, the interaction between magnetic $\mathrm{X}$ genotype had no significant effect on chlorophyll a and total chlorophyll content. The third interaction of salt levels $\mathrm{X}$ genotypes $\mathrm{X}$ magnetic had significant effect on chl. a / chl. $\mathrm{b}$ ratio but had no significant effect on chlorophyll a, b and total chlorophyll content. The highest value of chl. a/chl. b was 3.08 to Giza 6 with magnetic at $50 \mathrm{mM}$ $\mathrm{NaCl}$ and the lowest value was 1.19 to Giza 6 without magnetic at $50 \mathrm{mM} \mathrm{NaCl}$.

Similar results are obtained by El-Rodeny and ELOkkiah (2012). The observed reduction in chlorophyll content under $\mathrm{NaCl}$ stress could be attributed to the destruction of chlorophyll pigments and the instability of the pigment protein complex (Saad-Allah, 2015). It is also attributed to the interference of the salt ions with the synthesis of proteins, the structural component of chlorophyll, rather than the breakdown of chlorophyll (Jaleel et al., 2008). The increased pigment at high salt concentration $(100 \mathrm{mMNaCl})$ has previously been attributed to decreasing leaf growth in response to salinity stress (García-Sánchez et al., 2002). Pandolfi et al. (2012) suggested that stress may trigger a set of physiological alterations enabling the plants to withstand severe salinity. As was observed in our results, high salinity stress $(100 \mathrm{mMNaCl})$ tended to enhance the chlorophyll a, b and total chlorophyll content (Table 3). These results were agreement with those reported by Shah et al., 2017. The results of the effect of magnetic on chlorophyll pigment were disagreement with those reported by Al-Khazan et al., 2011.

\section{CONCLUSION}

Increasing salinity stress decreased all growth parameters, shoot/root ratio on fresh and dry weight basis and electrolytes leakage of the two groundnut genotypes at seedling stage. However, chlorophyll content and moisture content of whole plant, shoots and roots were increased with increasing salt stress. The N.C. genotype was more sensitive to salinity than the Giza 6 genotype for most growth attributes. The magnetized saline irrigation water had no significant effect on alleviation of the salt stress on the two groundnut genotypes. 


\section{REFERENCES}

Abdelraouf, E.A.A. 2017. Effect of presoaking sugar beet (Beta vulgaris L.) seeds with gibberellic, abscisic or ascorbic acids on alleviation of salinity stress. Alex. Sci. Exch. J., 38(1): $74-81$.

Abdelraouf, E.A.A., and A. Elgarhy. 2017. Response of different soybean (Glycine max L.) genotypes grown in sand culture to salinity stress. Alex. Sci. Exch. J., 38(4): $810-818$.

Al-Khazan, M., B.M. Abdullatif and N. Al-Assaf. 2011. "Effects of magnetically treated water on water status, chlorophyll pigments and some elements content of jojoba (Simmondsia chinensis L.) at different growth stages." Afr. J. Environ. Sci. Technol., 5(9): 722 - 731.

Aly, M.A., M.E. Thanaa, S.M. Osman and A.A.A. Mazek 2015. Effect of magnetic irrigation water and some antisalinity substances on the growth and production of Valencia orange. Middle East J. Agric. Res., 4(1): 88 - 98.

Arnon, D.I. 1949. Copper enzymes in isolated chloroplasts. I. polyphenoloxidase in Beta vulgaris. Plant Physiol., 24(1): $1-15$.

Aydinşakir, K., D. Büyüktaş, N. Dinç, and C. Karaca. 2015. Impact of salinity stress on growing, seedling development and water consumption of peanut (Arachis hypogaea cv. NC-7). Akdeniz Univ. Ziraat Fak. Derg., 28(2): 77 - 84.

Ayers, R.S., and D.W. Westcot. 1985. Water Quality for Agriculture. FAO Irrig. \& Drain. Paper 29. Rome.

Cachorro, P., A. Ortiz, and A. Cerdá. 1993. Effects of saline stress and calcium on lipid composition in bean roots. Phytochemist., 32:1131 - 1136.

Coombs J., G. Hind, R.C. Leegood, L.L. Tieszen and A. Vanshak. 1987. Analytical Techniques. In: Coombs J, Hall DO, Long SP, Scurlock JMO (eds), Techniques in bioproductivity and photosynthesis, pp. 219-227. Pergamon Press, Elmsford, New York.

CoStat. 2005. Cohort Software. 798 Lighthouse Ave., PMB 320 Monterey, USA.

Dash, M., and S.K. Panda. 2001. Salt stress induced changes in growth and enzyme activities in germinating Phaseolus mungo seeds. Biologia Plantarum, 44(4): 587 - 589.

Dkhil, B.B., and M. Denden. 2012. Effect of salt stress on growth, anthocyanin, membrane permeability and chlorophyll fluorescence of Okra (Abelmoschus esculentus L.) seedlings. Amer. J. Plant Physiol., 7(4): 174 - 183.

El-Rodeny, W.M. and S.A.F. EL-Okkiah. .2012. Physiological and anatomical changes in Glycine $\max$ L. under salinity stress. Egypt. J. Bot. 2nd Int. conf., 29 - 30 April, Minia Univ., pp. $37-50$.

F.A.O. Land and water resources information system in Egypt, 2007.

http://www.fao.org/WAICENT/FAOINFO/AGRICULT/A GL/sw1wpnr/sw1wpnr.htm.109
Farhoudi, R., A. Modhej and A. Afrous. 2015. Effect of salt stress on Seedlings growth and ions homeostasis of soybean (Glysin max) cultivars. J. Sci. Res. Develop., 2(5): $118-121$.

Gao, Y., Y. Sun, R. Zhang and G. Chu. 2017. Effects of magnetic water irrigation on the growth, $\mathrm{N}$ uptake and antioxidant enzyme activities of cotton seedlings. J. Agri. Sci. and Technol., B 7: 25 - 33.

García-Sánchez, F.; Jifon, J.L.; Carvajal, M.; Syvertsen, J.P. Gas exchange, chlorophyll and nutrient contents in relation to $\mathrm{Na}+$ and $\mathrm{Cl}-$ accumulation in 'sunburst' mandarin grafted on different rootstocks. Plant Sci. 2002, 162, 705-712.

Hasegawa P.M., R.A. Bressan, J.K. Zhu and H.J. Bohnert. 2000. Plant cellular and molecular responses to high salinity. Ann. Rev. Plant Physiol. Plant Mol. Biol., 51: 463-499.

Hewitt, E.G. 1966. Sand and Water Culture Methods Used in the Study of Plant Nutrition. Technical Communication No. 22. 2nd ed. Commonwealth Agricultural Bureaux, Fornham Royal, England.

Jaleel, C.A., B. Sankar, R. Sriaharan and R. Panneerselvam. 2008. Soil salinity alters growth, chlorophyll content, and secondary metabolite accumulation in Catharanthus roseus. Turk. J. Biol., 32: $79-83$.

Jeyapraba, J., S. Mahendran, and N. Sujirtha. 2016. Growth physiology and membrane permeability of Okra (Abelmoschus esculentus L.) seedlings as affected by salinity. Inter. J. Plant \& Soil Sci., 9(5): 1 - 5.

Läuchli, A., and E. Epstein. 1990. Plant Responses to Saline and Sodic Conditions. In: Agricultural Salinity Assessment and Management, ed. K.K. Tanji, ASCE Manuals and Reports on Engineering Practice \#71, Chapter 6, pp. 113-137.

Maheshwari, B.L. and H.S. Grewal. 2009. Magnetic treatment of irrigation water: Its effects on vegetable crop yield and water productivity. Agric. Water Manage., 96(8): 12291236.

Mostafazadeh-Fard, B., M. Khoshravesh, S.F. Mousavi and A.R. Kiani. 2011. Effects of magnetized water on soil sulphate ions in trickle irrigation. In, 2nd Int. Conf. Environ. Eng. and Appl., IACSIT Press (pp. 94-99). Singapore.

Munns R. 1993. "Physiological processes limiting plant growth in saline soil: Some dogmas and hypotheses," Plant, Cell \& Environ., 16: 15 - 24.

Munns, R. and R.A. James. 2003. Screening methods for salinity tolerance: a case study with tetraploid wheat. Plant and Soil, 253(1): 201-218.

Nikee, E., A. Pazoki and H. Zahedi. 2014. Influences of ascorbic acid and gibberellin on alleviation of salt stress in summer savory (Satureja hortensis L.). Int. J. Biosci., 5(4): $245-255$.

Pandolfi, C., S. Mancuso and S. Shabala. 2012 Physiology of acclimation to salinity stress in pea (pisum sativum). Environ. Exp. Bot., 84: 44-51. 
Radhakrishnan, R. and B.D.R. Kumari. 2012. Pulsed magnetic field: A contemporary approach offers to enhance plant growth and yield of soybean. Plant Physiol. and Biochem., 51: $139-144$.

Saad-Allah, K. M. 2015. Impact of sea salt stress on growth and some physiological attributes of some soybean (Glycine max L.) varieties. Iranian J. Plant Physiol., 6(1): $1559-1571$.

Seemann, J.R. and T.D. Sharkey. 1986. Salinity and nitrogen effects on photosynthesis, ribulose-1,5-bisphosphate carboxylase and metabolite pool sizes in Phaseolus vulgaris L. Plant Physiol., 82(2): 555 - 560.

Shah, S.H., R. Houborg and M.F. McCabe. 2017. Response of chlorophyll, carotenoid and SPAD-502 measurement to salinity and nutrient stress in wheat (Triticum aestivum L.). Agron., 7: 61.
Shannon, M.C. 1998. Adaptation of plant to salinity. Adv. Agron., 60: 75-119.

Taiz, L., and E. Zeiger. 1998. Plant Physiology. 2nd Edition. Sinauer Associates Ins. Publisher, Sunderland, Massachusetts, USA.

Tester M. and R. Davenport. 2003. $\mathrm{Na}^{+}$tolerance and $\mathrm{Na}^{+}$transport in higher plants. Ann. Bot., 91: 503 - 507.

Werner, J.E., and R.R. Finkelstein. 1995. Arabidopsis mutants with reduced response to $\mathrm{NaCl}$ and osmotic stres. Physiol. Plantarum, 93(4): 659 - 666.

Yousef, S.A. and I.S. Al-Saadawi. 1997. Effect of salinity and nitrogen fertilizaton on osmotic potential and elements accumulation in four gentypes of broad bean Vicia feba $\mathrm{L}$. Dirasa Agric. Sci., 24: 395 - 401.

\section{الملخص العربي \\ استجابة تراكيب وراثية مختلفة من الفول السوداني للري بمياه مالحة ممغنطه}

$$
\text { السيد عبد الرووف عبدالله عبد الرووف، شيماء محمد عبد العزيز }
$$

لكل أصيص. بعد ثلاثة أسابيع من الزراعة، تم حصاد

النباتات بالكامل. أثارت النتائج إلى أن زيادة الإجهاد

الملحي قلل من جميع قياسات النمو ونسبة المجموع

الخضري/ الجذري على أساس الوزن الطازج والجاف لكلا

التركيبين الوراثيين من الفول السوداني. إلا أنه قد زاد

المحتوى الرطوبي للنبات الكامل والمجموع الخضري والجذور

مع زيادة إجهاد الملح. انخفض تسرب الإكتروليتات بشكل

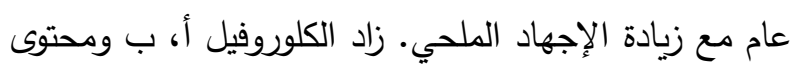

الكلوروفيل الكلي عند المستوى العالي من إجهاد الملح (. (. 1.

ملي كلوريد الصوديوم). كان التركيب الوراثي N.C. أكثر مإن

حساسية للملوحة من الصنف جيزة 7 لمعظم سمات النمو. لم

يكن لمياه الري المالحة الممغنطة تأثيراً معنوياً على تخفيف تأثير الإجهاد الملحي على كل من التركيبين الوراثيين المختبرين من الفول السوداني.
أجريت هذه الدراسة في محطة بحوث إيتاي البارود، مركز

البحوث الزراعية، وزارة الزراعة، مصر ، أثناء الموسم الصيفي

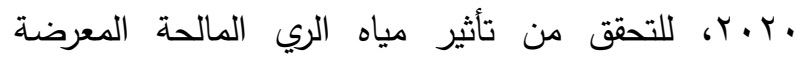
للمعالجة المغناطيسية على نمو تركيبين وراثيين من الفول السوداني. نفذت التجربة في تصميم قطاعات عشوائية كاملة في مصفوفة منشقة مرتين بثلاثة مكررات. كانت القطع

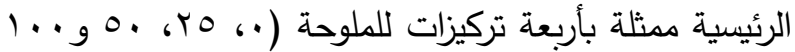
ملليمول كلوريد صوديوم)، وكانت القطع الفرعية عبارة عن تركيبين وراثيين من الفول السوداني (جيزة 7 و N.C. وكانت القطع تحت الفرعية عبارة عن معاملتين (الري بمحلول ري ممغنط أو بدون مغنطه). زرعت البذور في أصص تحتوي على ه. • كجم من رمل الكوارتز المغسول مسبقًا وتم ريها ثلاث مرات في الأسبوع عن طريق إضافة من ... مل من محلول الري المكون من محلول مغذي أساسي ومستوى الملح المعرض أو غير المعرض لمجال مغناطيسي (محلول عادي) 